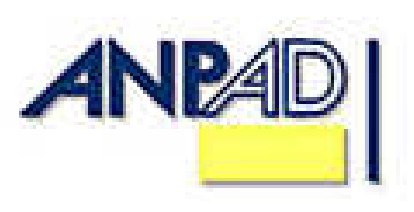

Available online at

http://www.anpad.org.br/bar

\title{
The Variance Composition of Firm Growth Rates
}

\author{
Luiz Artur Ledur Brito * \\ E-mail address: luiz.brito@fgv.br \\ Escola de Administração de Empresas de São Paulo, Fundação Getúlio Vargas - EAESP/FGV \\ São Paulo, SP, Brazil.
}

Flávio Carvalho de Vasconcelos

E-mail address: flavio.vasconcelos@fgv.br

Escola Brasileira de Administração Pública e de Empresas - EBAPE/FGV

São Paulo, SP, Brazil.

\section{ABSTRACT}

Firms exhibit a wide variability in growth rates. This can be seen as another manifestation of the fact that firms are different from one another in several respects. This study investigated this variability using the variance components technique previously used to decompose the variance of financial performance. The main source of variation in growth rates, responsible for more than $40 \%$ of total variance, corresponds to individual, idiosyncratic firm aspects and not to industry, country, or macroeconomic conditions prevailing in specific years. Firm growth, similar to financial performance, is mostly unique to specific firms and not an industry or country related phenomenon. This finding also justifies using growth as an alternative outcome of superior firm resources and as a complementary dimension of competitive advantage. This also links this research with the resource-based view of strategy. Country was the second source of variation with around $10 \%$ of total variance. The analysis was done using the Compustat Global database with 80,320 observations, comprising 13,221 companies in 47 countries, covering the years of 1994 to 2002. It also compared the variance structure of growth to the variance structure of financial performance in the same sample.

Key words: variance components; growth; competitive advantage.

Received 04 March 2008; received in revised form 12 February 2009.

Copyright (C) 2009 Brazilian Administration Review. All rights reserved, including rights for translation. Parts of this work may be quoted without prior knowledge on the condition that the source is identified.

\footnotetext{
* Corresponding author: Luiz Artur Ledur Brito

Fundação Getulio Vargas - SP, Av. Nove de Julho, 2009, 10 andar, Bela Vista, São Paulo, SP, 01313-902, Brazil.
} 


\section{INTRODUCTION}

Some firms grow at impressive rates while others, sometimes rather similar ones, stagger or even shrink in size and end up disappearing from the business context by being acquired by the successful ones or simply ceasing to continue their activities. This wide variance in individual growth rates is just another aspect of the fact the firms differ in several dimensions (Carroll, 1993; Nelson, 1991).

What reasons lie behind this heterogeneity in firm growth rates? Is firm growth closely related to industry structure or to industry evolution, as Keppler and his associates imply (Keppler, 1996; Keppler \& Grady, 1990; Keppler \& Simons, 2000)? Or, maybe, firm growth is heavily influenced by country, or institutional context (North, 1992; Porter, 1990). Finally, firm growth may be firm specific. Some firms, with superior resources, grow faster while others, due to the inadequacy of their resources, do not succeed. This is basically the approach of the original work of Penrose (1959) and an extension of the development of the resource-based view of strategy, applied to growth. How can we balance out all these sources of variability and assess their relative influence? This paper makes a contribution to help understand these specific questions.

A well-known, and currently active, line of research in strategy has dealt with a similar question when analyzing the variance components of firm financial performance, using profitability measures. This line of research was introduced by the seminal papers of Schmalensee (1985) and Rumelt (1991) and further developed by several other authors uncovering many of the factors underlying the observed heterogeneity in firm performance (Bowman \& Helfat, 2001; Brush \& Bromiley, 1997; Brush, Bromiley, \& Hendrickx, 1999; Hawawini, Subramanian, \& Verdin, 2003; Makino, Isobe, \& Chan, 2004; McGahan \& Porter, 1997, 2003; McNamara, Vaaler, \& Devers, 2003; Misangyi, Elms, Greckhamer, \& Lepine, 2006; Roquebert, Phillips, \& Westfall, 1996). It is now well established that firm effects are the most relevant source of variation in financial performance. Firm effects are associated with idiosyncratic firm characteristics and are not shared by other firms. Corporate effects also seem to be particularly relevant in more recent times (Bowman \& Helfat, 2001; McNamara et al., 2003). Industry effects are a secondary source of variability but McGahan and Porter (1997) argued that in some economic sectors, other than manufacturing, its relevance is greater and they also show stronger persistence than firm effects (McGahan \& Porter, 2003). Year effects, associated to factors that affect all firms in certain years, are usually small or nonexistent. Finally, recent work has explored the variability of performance outside the United States introducing other sources of variability such as belonging to business groups in emerging economies (Khanna \& Rivkin, 2001) or the effect of the country of operation (Makino et al., 2004). This line of research has also drawn the attention of Brazilian academics (Bandeira-de-Mello \& Marcon, 2005; Brito \& Vasconcelos, 2004; Gonçalves \& Quintella, 2006). These also focused on profitability as the relevant dependent variable and found the pattern of variability of Brazilian companies is similar to the samples studied in the international literature.

This research question has great relevance for strategic management. Strategy, unlike economics, concerns itself with individual firms rather than industries. The economist sees the firm as a player in a game. The game, not the player, however is the object of interest (Nelson, 1991). The fact that most of the observed variability in financial performance is firm or corporation specific lends empirical support and relevance to strategy itself as a field of inquiry and to the resource-based view when compared with other approaches like industry analysis or environmental scanning.

Although different forms of operationalization of financial performance have been explored, leading to similar results (Hawawini et al., 2003; McGahan, 1999; Powell, 1996), it has been restricted to profitability measures and growth has never been considered as an alternative outcome. In fact, most of the empirical research on firm growth has been of an econometric nature, building on the original work of Gibrat (1931). Sutton (1997) recently provided a comprehensive review. Most of these works develop a model with different assumptions of firm growth mechanism, but the real interest is the industry structure as an outcome. These results show the existence of firm (Evans, 1987b); Hall, 
1987), industry (Dunne, Roberts, \& Samuelson, 1989; Hall, 1987; Singh \& Whittington, 1975), and year effects (Dunne et al., 1989; Hall, 1987), but are not able to give the relative importance and magnitude of each. The approach taken in this paper bridges this gap.

Understanding the regularities underneath the variability of firm growth rates has significant relevance for strategy in several dimensions. From the practitioner of consultant point of view, profitability and growth can be competing or complementary objectives and understanding the nature of the variability in both can support better decisions. Geroski, Machin and Waters (1997) have argued that growth is more erratic and less predictable than profitability and for this reason, the preferred choice, if any, should favor the former rather than the latter. The findings of this research challenge such a conclusion. For those responsible for deciding on public policy issues, understanding this variability is crucial. If industry effects are of lesser importance, as the findings of this research suggest, traditional policies targeted at specific industries may not be the most effective action. Finally, from the perspective of the theorist, if firm growth is fundamentally specific to the individual firm, as the results of this research suggest, growth can be seen as an outcome of superior resources and as an additional dimension of the outcome of competitive advantage. The competitive advantage construct has been linked to rents in most of the theoretical development of the RBV. Why not see growth as evidence of a competitive advantage?

The first texts covering the notion of competitive advantage presented the evidence of success, normally as increased market share and dominance, in other words, growth (Ansoff, 1965; Gluck, Kaufman, \& Walleck, 1980; Ohmae, 1978; South, 1981). Growth is also at the foundations of the resource-based view of strategy through the fundamental work of Penrose (1959), acknowledged by most authors as one of the founders of the RBV (Barney, 1991; Cooner, 1991; Grant, 1991; Mahoney \& Pandian, 1992; Peteraf, 1993; Wernerfelt, 1984; Williams, 1994). Some voices, however, have been heard contesting this and pointing to the forgotten dimension of growth in the current literature of RBV so centered on rents. Foss (2002) argues that the influence of Penrose (1959) in the RBV, as it developed, is small. Penrose (1959) concerns herself with the phenomenon of disequilibrium and growth while the RBV attempts to explain rents above norm in an equilibrium state. A similar argument is used by Rugman and Verbeke (2002). Maybe the approach used by the RBV so far is limited and it should go back to its roots and look more deeply into the growth and disequilibrium too. This paper can also be seen as a contribution in this direction.

The next section reviews some of the relevant literature on previous studies using variance components analysis of financial performance, the resource-based view and its link to the phenomenon of growth, and the previous econometric studies on growth rates. The data and method are then presented. The results and their discussion form the main part of the paper and a conclusions section summarizes them and explores limitations and future studies.

\section{LITERATURE REVIEW}

\section{Previous Studies on Variance Components of Performance}

This line of research in strategy started with the paper of Rumelt (1991). His source of data was the FTC [Federal Trade Commission] database covering the return on assets of 1174 business units during the years of 1974 to 1977. He expanded the previous analysis of Schmalensee (1985) and identified the so called firm effects. These accounted for $46.4 \%$ of total variance, being the most important source of variation. Industry effect alone was responsible for $8.3 \%$ of total variance and the industry year interaction for another 7.4\%. A small corporate effect of $0.8 \%$ and no year effect made up for the rest of the explained variance that reached $63.3 \%$ of total variance. These results were used to support the then-emerging resource-based view of strategy in opposition to the positioning school derived from the industry analysis and led by Porter (1985). 
Roquebert et al. (1996) published a similar study using a much larger database (Compustat) and covering the period ranging from 1985 to 1991 . Their model explained $68.0 \%$ of total variance, and the most important effect was again firm effect, with 37.1\%. Contrary to Rumelt (1991) they found an important corporate effect, with $17.9 \%$. Industry accounted for $10.2 \%$ and industry-year interaction for 2.3\%. A long debate established itself around the issue of corporate effects (Bowman \& Helfat, 2001; Brush \& Bromiley, 1997; Brush et al., 1999; Chang \& Singh, 2000; McNamara et al., 2003). It is now clear the results of Rumelt were very sensitive to sample, that corporate effect is relevant, and its importance seems to have increased during the eighties and nineties (McNamara et al., 2003). McGahan and Porter (1997) published research also using the Compustat database, but using a much larger dataset with 72,742 observations covering business units' results from 1981 to 1994 . They found the variance structure was substantially different when the different economic sectors (or SIC divisions as defined in this paper) were analyzed separately. For manufacturing, the economic sector analyzed in previous studies, they found a similar variance composition with firm effect of $35.4 \%$, industry effect of $10.8 \%$, and year effect of $2.3 \%$. In other economic sectors, industry influence was greater, reaching, for example, $47.4 \%$ in services. In the total sample, firm effects were still the largest effect with $31.7 \%$, industry $18.7 \%$, and corporation $4.3 \%$.

Other forms of measurement of financial performance were explored by McGahan (1999) and Hawawini et al. (2003) with similar results. All these studies were concerned with the business environment in the U.S. Claver, Molina and Tari (2002) analyzed 679 Spanish companies from 1994 to 1998 and also found firm effects of $42.7 \%$ and industry effects of only $4.8 \%$. The Brazilian environment has also been studied by several authors, always using profitability measures, finding similar results (Bandeira-de-Mello \& Marcon, 2005; Brito \& Vasconcelos, 2004; Gonçalves \& Quintella, 2006; Moraes, 2005).

\section{Growth as a Forgotten Dimension in the Resource-Based View of Strategy}

Growth as an outcome of the utilization of resources was present in the initial ideas that formed the resource-based view of strategy as a body of knowledge. In particular, Penrose (1959), who saw firm growth as the most important dependent variable, was one of the most influential works in the development of the RBV, and as a true founder of it (Barney, 1991; Cooner, 1991; Grant, 1991; Mahoney \& Pandian, 1992; Wernerfelt, 1984; Williams, 1994). Cockburn, Henderson and Stern (2000) used the term canonical reference to describe the impact of Penrose (1959) in the area. Wernerfelt (1984) and Mahoney and Pandian (1992) also considered and presented growth as one of the results derived from superior resources, but did not develop the theme further. Also the original Barney (1991) definition of competitive advantage does not conceptually exclude growth as a dimension of it. Even the text of Peteraf (1993) mentions growth and the author excuses herself for using only a cost example to illustrate the economic interpretation of competitive advantage.

Some early texts (Allen, 1978; Gluck et al., 1980; Morrisson \& Lee, 1979; Ohmae, 1978) saw competitive advantage as broad evidence of success and growth or market gain were more common in the examples than rents above the norm. The formal development of the RBV, however, seems to have forgotten the growth dimension, focusing almost exclusively on rents above the norm. Growth is central in the influential text of Mahoney and Pandian (1992) available in mimeo since 1990. The idea seems to have been forgotten since then. Even Lippman and Rumelt (2003) who challenged the cornerstone issue of economic profit did not mention growth.

This static view of rents, whose dynamic issue is only the sustainability of these rents, is seen as one of the limitations of the present state of the RBV (Priem \& Butler, 2001). This point is also developed by Rugman and Verbeke (2002) when they review Penrose's (1959) contribution to the strategic management area. They point out that the contribution of Penrose (1959) is not in the rents derived from resources and from the isolating mechanisms that allow them to be sustained. Penrose (1959) considered that rents were not a critical objective, but much more instrumental to the process of growth and a result of it (Rugman \& Verbeke, 2002, p. 775). Penrose (1959) explicitly rejected the 
equilibrium, and so also the profitability above norm being sustained in the long run. Her perspective can be seen as value creation in opposition to value appropriation.

By analyzing growth and by assessing how much of the observed variability in growth rates can be associated to firm specific effects, this paper can be seen as a contribution to this debate. It supports the view that value creation of the competitive advantage that leads to it are multidimensional in nature and that growth can be taken as one of these dimensions. In a simple way, competitive advantage could be seen as a composition of two vectors: growth and rents. Resources could be used to promote one or both of these vectors.

\section{Econometric Studies on Growth Variability}

One of the approaches in industrial organization to deal with firm growth is the development of stochastic models where most of the variation in growth rates, sometimes all of it, is the result of a random process. This approach developed into one of the most important lines of research on market structure (Sutton, 1997). At the foundation of this line of research is the classic work of Gibrat (1931) who formulated an assumption that was later named Gibrat's Law or Law of Proportionate Effect. It states, in its simplest form, that growth rates are independent of size so large firms have equal chances of having similar growth rates to small firms, differences being caused by purely random variation around similar means.

If applied in its pure form to a constant population of firms, size dispersion and industry concentration would increase indefinitely (Scherer \& Ross, 1990, pp. 141-143). Many of the earlier works on this topic proposed models that could be fitted to data, modifying, refuting or complementing Gibrat's Law (Hart \& Prais, 1956; Hymer \& Pashigian, 1962; Simon, 1955; Simon \& Bonini, 1958). The subject of interest was the resulting industry structure rather than understanding individual firm growth.

Mansfield (1962) analyzed extensively some industries in the U.S. and besides finding evidence against Gibrat's Law in all its forms, found indications of industry and firm effects. First, the different industries had clearly different growth rates pointing out industry influence. Second, he explored the effect of innovation, finding that firms that had introduced innovations in product or process grew twice as fast as firms that had not introduced such innovations. This was a clear indication of firm effects. Ijiri and Simon (1974) introduced improved models where growth rates had different forms or autocorrelation. This could also be explained by assuming the existence of firm effects. Evans (1987a) presented a broad study using the Dun \& Bradstreet database with more than 20,000 American companies from 1976 to 1982, measuring growth rates by change in number of employees. $\mathrm{He}$ introduced the variable firm age and found that older firms grow more slowly than younger firms, an indication of firm effect. The same age effect was confirmed by Dunne et al. (1989) in a different sample of over 200,000 industrial plants. In a second study, using an even larger sample, Evans (1987b) found that this effect varies by industry.

Hall (1987) used the Compustat database to analyze 1778 firms in the manufacturing sector from 1972 to 1983. Again, the number of employees was used to measure growth. He found that investment in the plant and equipment and investment in research and development positively influenced firm growth. Investment in $\mathrm{R} \& \mathrm{D}$ was twice as effective compared to investment in plant and equipment. Hall (1987) also found evidence of strong industry effects: "There are substantial differences across industries, with the so called 'high tech' industries (drugs, computing equipment, and scientific instruments) typically growing more rapidly throughout both periods" (Hall, 1987, p. 586). Sutton (1995) developed a model with what he called a boundaries approach. In this model he accounted for strategic interactions of firms within groups in an industry. The model is able to forecast boundary curves for industry concentration which were compared with empirical data. The dispersion of points differs by country suggesting a possible country effect. 
Geroski et al. (1997) analyzed 271 large corporations in the United Kingdom, from 1976-1982. They developed a model that tried to predict growth rate using as an independent variable the expectation of the future value of the firm. Results were presented with some degree of frustration by the authors since the complete and complex regression used was capable of explaining only $18.6 \%$ of total variance in growth rates. Based on this and other observations the authors concluded that firm growth was almost purely stochastic and the Gibrat's Law with some adaptations could be adequate to describe it. This structure of variability was compared with that of profitability, which exhibited much more regularities and less random influence. The preference some managers give to growth at the expense of profitability could be regarded as a paradox since growth was a much more uncertain outcome than profit. The results of this research challenge directly this conclusion using a more adequate method and a much larger and broader sample.

A common finding in several of the works in this line of research is that variability in growth rates reduces as size increases. Large companies show less variability in growth rates than smaller ones (Dunne et al., 1989; Evans, 1987a; Hall, 1987; Kumar, 1985; Mansfield, 1962; Singh \& Whittington, 1975). In that regard to the direct relationship between size and growth rates (the essence of Gibrat's Law) results are mixed, but the most recent studies indicate a weak negative relationship between these variables. Larger companies therefore grow at slower rates than smaller ones. This relationship, however, seems to be moderated by industry factors like innovation in the industry (Hall, 1987).

The common methodological approach of this line of research was to build different firm growth models, derive the consequences of this model to industry structure and then compare the resulting industry structures with the observed ones, validating or not the model and its assumptions. None of these studies could, however, offer a comparative analysis of the different sources of variation in growth rates.

\section{METHOD}

\section{Data and Sample}

The Compustat Global database was the original source of data. This database is compiled and maintained by Standard and Poor's and collects financial and market data from companies in more than 80 countries since 1991. Data for this research were extracted using the Industrial Active and Industrial Research sets of companies. Total revenue and total assets are available in the database in both local currency and in US dollars using the exchange rate of each period. Growth rates based on these figures are not totally valid and comparable between themselves since they include local inflation and currency exchange effects. An extensive work of data normalization was then performed to reach comparable growth rates. Each country, for which a relevant amount of data was available, was analyzed individually identifying currency changes (like the changes to Euro reporting in European countries) and the GDP deflator published by the World Bank was used to account for inflation and convert all figures to the same basis. At the end of this process, countries with less than 50 observations were eliminated since country effects would not be reliable. Following McGahan and Porter (1997) and most of the previous studies on variance components companies with less than US $\$ 10,000,000$ in revenue were also eliminated. Final analysis was done on 80,320 observations, comprising 13,221 companies in 47 countries, covering the years of 1994 to 2002.

\section{Constructs and Variables}

The concept of firm growth is broader than the simple increase in an index such as total sales or number of employees. Growth implies a development process (Penrose, 1959), similar to biological processes where the change in size in accompanied by a change in characteristics of the object under study. Any operationalization can capture only part of this broader concept. Penrose (1959, pp. 25, 198-199) recognizes all these difficulties and suggests total fixed assets as a tentative 
operationalization. Other authors used different approaches. Total sales was a frequent choice (Acs \& Audretsch, 1990; Caves, 1998), although it does not capture changes in the degree of vertical integration of the business (Penrose, 1959). Number of employees was another choice (Dunne et al., 1989; Hall, 1987). Baum Locke and Smith (2001) used a multidimensional measure based on sales, number of employees and profits. In this research, we used two operationalizations to measure growth: growth in total revenue and growth in total assets, allowing some indication of convergent validity.

Another aspect is the period of time through which growth rates are to be calculated. Annual growth rates are the immediate choice, but we also included compound growth rates for periods of two and three years. After accounting for inflation and currency effects, growth rates were calculated as follows:

Total revenues growth rates:

$$
\begin{aligned}
& \text { CRESCREC }_{1}=\left(\text { REVT }_{t} / \text { REVT }_{\mathrm{t}-1}-1\right) \times 100 \\
& \text { CRESCREC }_{2}=\left(\left(\operatorname{REVT}_{\mathrm{t}} / \operatorname{REVT}_{\mathrm{t}-2}\right)^{1 / 2}-1\right) \times 100 \\
& \text { CRESCREC }_{\mathrm{t}}=\left(\left(\operatorname{REVT}_{\mathrm{t}} / \operatorname{REVT}_{\mathrm{t}-3}\right)^{1 / 3}-1\right) \times 100
\end{aligned}
$$

Total assets growth rates:

$$
\begin{aligned}
& \text { CRESCAT }_{\mathrm{t}}=\left(\mathrm{AT}_{\mathrm{t}} / \mathrm{AT}_{\mathrm{t}-1}-1\right) \times 100 \\
& \text { CRESCAT }_{\mathrm{t}}=\left(\left(\mathrm{AT}_{\mathrm{t}} / \mathrm{AT}_{\mathrm{t}-2}\right)^{1 / 2}-1\right) \times 100 \\
& \text { CRESCAT }_{\mathrm{t}}=\left(\left(\mathrm{AT}_{\mathrm{t}} / \mathrm{AT}_{\mathrm{t}-3}\right)^{1 / 3}-1\right) \times 100
\end{aligned}
$$

\author{
annual growth rate \\ compound two years growth rate \\ compound three years growth rate
}

annual growth rate

compound two years growth rate

compound three years growth rate

Industry membership was identified by the Standard Industry Classification [SIC] code, available in the database. Although for U.S. companies a full four-digit code was available, in several countries the code was assigned in an aggregated form using the last digit as a zero, or, in practice, identifying the industry with a three-digit code. In several cases, the aggregation was done at an even higher level using a two-digit code. In most analyses, unless noted otherwise, the three-digit code was used. Country membership was considered to be the country where the firm publishes its results, so this is better understood as country of origin rather than country of operation.

Following the approach for most of the previous empirical research in the field, we did not distinguish between the different processes leading to firm growth: mergers and acquisitions and endogenous growth (Geroski et al., 1997; Hall, 1987; Hart \& Prais, 1956; Mansfield, 1962; Singh \& Whittington, 1975). Again, data limitations were the main reason for this approach but it also has a theoretical foundation since both are competing processes for the same phenomenon (Penrose, 1959).

\section{Treatment of Extreme Observations}

The distributions of growth rates obtained showed some extreme observations that deserved some treatment. Since growth is a ratio variable, sometimes the denominator could be small, yielding high growth rates over a small basis. In other cases, companies could almost disappear from one year to another producing negative growth rates close to $-100 \%$. Accounting errors or large acquisitions or divestitures could also cause these extreme values. Although outliers removal may discard especially interesting data and limit generalization, we invoke here the issue of construct validity, and took the view that the construct we want to investigate does not relate to these extreme values of growth rates. If a company grows $1000 \%$ in a year, or shrinks in size to $1 \%$ of its previous state (showing a $-99 \%$ growth rate), this rate does not reflect the construct we are interested in, but represents a special condition. The growth we wish to investigate is the more run-of-the-mill type that represents the reality of most companies and managers. Several combinations of cut-off limits for the growth rates ranging from $-70 \%$ to $+200 \%$ were tried and their effect on final results of a trial sample investigated. 
Results proved to be robust to these limits, so final choice was to eliminate growth rates lower than $50 \%$ and higher than $100 \%$. The percentage of discarded observations did not exceed $5 \%$.

\section{The Variance Components Procedure}

Searle, Casella and McCulloch (1992) provide a comprehensive treatment of the variance components technique. In the case under study, firm, industry sector, year and country are taken as random effects, each contributing to the total variance of the observable variable. The basic model, without considering possible interactions was:

$$
r_{i, j, k, t}=\mu+\gamma_{t}+\alpha_{i}+\beta_{j}+\phi_{k}+\varepsilon_{i, j, k, t}
$$

Where $r_{i, j, k, t}$ was the growth measure of an individual company in the sample. The index $t$ represented the different years considered; $i$ the different industry sectors; $j$ the country of origin; and $k$ the individual firms. The term $\mu$ was the average result of all companies taken as a group. The term $\gamma_{t}$ was the year effect, $\alpha_{i}$ the industry sector effect, $\beta_{j}$ accounted for country effect and, finally, $\phi_{k}$ was the individual contribution of the company $k$ to its growth, or the firm effect. The error term $\varepsilon_{i, j, k, t}$ was the residual, not explained by the model. This simple model can be extended including the possible interactions of country, industry and year by adding three other terms accounting for country-industry, country-year and industry-year interactions.

The variance of the term $r_{i, j, k, t}$ was given by:

$$
\sigma_{r}^{2}=\sigma_{\gamma}^{2}+\sigma_{\alpha}^{2}+\sigma_{\beta}^{2}+\sigma_{\phi}^{2}+\sigma_{\varepsilon}^{2}
$$

\section{RESULTS AND DISCUSSION}

\section{The Distribution of Firm Growth Rates}

The distributions of all operationalizations of growth rates showed a similar pattern. The standard deviations gradually decreased as the level of aggregation in time increased from the annual rate to the three year compound growth rate, indicating that yearly variations were compensated. Distributions also showed a slight deviation from normality by being slightly asymmetrical and leptocurtic.

The first point to note is the managerial relevance of the observed dispersion. The three year compound growth rate had a mean of $7.46 \%$ and a standard deviation of 18.68 . This means that a firm, positioned one standard deviation above the mean, would have a growth rate of $26.14 \%$ while a firm, positioned one standard deviation below the mean, would have a growth rate of $-11.22 \%$ and would be shrinking in size. While the first case might be associated with great success, the second is evidence of a worrying and troublesome situation. Geroski et al. (1997) found, in a much smaller sample, a smaller standard deviation (11.65\%) but of the same order of magnitude.

The second point is the quasi-symmetry of the distribution. Combined with the values of the mean and standard deviation, this shows that growth below the norm is as frequent as growth above the norm and that nongrowth, or shrinking, is a common phenomenon. The theoretical development of Penrose (1959) seeing growth as a natural process, result of underutilized resources, always made available, and released after the growth happens, can well explain the positive growth rates, but cannot explain the negative ones. Where is the theory of nongrowth? Penrose $(1959, \mathrm{p} .7)$ only touches on this issue superficially, and suggests some reasons for nongrowth: unenterprising direction, inefficient management, insufficient capital-raising ability, lack of adaptability to changing circumstances, poor judgment leading to frequent and costly mistakes, or simply bad luck due to circumstances beyond 
their control. The relevance and frequency of nongrowth, indicated by these distributions, calls for further research and a stronger theoretical development to better understand it.

\section{The Variance Components for the Total Sample}

The variance composition of the six different operationalizations of firm growth rates are shown in Table 1, using a simple model of effects with no interactions. Parameters like mean, standard deviation and number of observations for each sample analyzed are also shown in the last three lines of Table 1. The number of observations is different in each case, and smaller than the original 80,320 observations, for several reasons. First, to calculate annual rates the base year is lost. Similarly two and three years are lost for the two and three year compound rates, respectively. Second, some observations had data for revenue, but not for total assets and vice versa. Third, these results were calculated using the full 3-digit SIC classification and some observations had only the 2-digit classification and had to be discarded.

Table 1: Variance Composition of Firm Growth Rates for the Total Sample

\begin{tabular}{|c|c|c|c|c|c|c|}
\hline & \multicolumn{2}{|c|}{ Annual } & \multicolumn{2}{|c|}{ two years Compound } & \multicolumn{2}{|c|}{ three years Compound } \\
\hline & Revenue & Assets & Revenue & Assets & Revenue & Assets \\
\hline Year & $3.5 \%$ & $3.7 \%$ & $3.0 \%$ & $3.2 \%$ & $1.4 \%$ & $1.4 \%$ \\
\hline Firm & $19.0 \%$ & $18.8 \%$ & $30.9 \%$ & $29.6 \%$ & $42.1 \%$ & $40.2 \%$ \\
\hline Country & $5.6 \%$ & $7.1 \%$ & $6.4 \%$ & $9.5 \%$ & $10.0 \%$ & $10.6 \%$ \\
\hline Industry & $3.4 \%$ & $1.9 \%$ & $5.4 \%$ & $3.1 \%$ & $7.3 \%$ & $5.1 \%$ \\
\hline Model & $31.5 \%$ & $31.4 \%$ & $45.6 \%$ & $45.4 \%$ & $60.7 \%$ & $57.3 \%$ \\
\hline Unexplained variance & $68.5 \%$ & $68.6 \%$ & $54.4 \%$ & $54.6 \%$ & $39.3 \%$ & $42.7 \%$ \\
\hline Total & $100.0 \%$ & $100.0 \%$ & $100.0 \%$ & $100.0 \%$ & $100.0 \%$ & $100.0 \%$ \\
\hline Mean & 7.26 & 5.57 & 7.42 & 6.77 & 7.46 & 7.65 \\
\hline Standard deviation & 22.14 & 20.77 & 20.35 & 20.02 & 18.68 & 19.10 \\
\hline Observations & 70970 & 69062 & 60569 & 58834 & 49706 & 48345 \\
\hline
\end{tabular}

Source: authors' analysis.

The first aspect to note is the convergence of results of the two operationalizations of growth (revenue and total assets). Differences are small, do not exceed a few percentage points and do not change the interpretation of variance structure. This indicates convergent construct validity, allowing us to interpret these results as representative of the broader construct firm growth.

The percentage of variance that could be explained by the model rose markedly from around $31 \%$ for the annual growth rates to $45 \%$ for the two-year compound growth rates and reached $57 \%$ to $60 \%$ for the three year compound growth rates. This indicates a greater randomness in the annual rates and the possible existence of a compensation mechanism from year to year as foreseen by Penrose (1959, p. 213) who argued that growth could happen in spurts. Geroski et al. (1997) concluded, using different empirical research, that corporate growth rates vary in a random and unpredictable way. Managers' preference for growth, possibly at the expense of a poorer financial performance, was questioned by them as illogical and lacking empirical support since financial performance presents greater regularities. The results of this research challenge this conclusion.

Firm effects, made up by idiosyncratic factors related to the individual firm, were clearly the main group of factors responsible for the explained variance by a large margin in relation to the second factor, country effects. The variability of firm growth rates depends much more on individual firm factors than on aspects of the environment where it operates as industry, country or the specific year in question. This finding offers excellent empirical support to the logic developed by Penrose (1959) and supports the resource-based view as a theoretical foundation to study growth. 
Previous studies on the nature and variability of firm growth rates already signaled the existence of firm effects (Dunne et al., 1989; Evans, 1987b; Hall, 1987; Kumar, 1985; Mansfield, 1962; Singh \& Whittington, 1975). Some of these studies even identified variables that could be related to firm effects such as age leading to smaller growth rates (Dunne et al., 1989; Evans, 1987a), or the issue of investment in physical assets and in research and development that would enhance growth rates (Hall, 1987). None of these studies, however, succeeded in assessing the relevance of firm effects relative to other classes of effects as we found in these results. The findings also suggest that other theoretical approaches to growth such as transaction costs (Coase, 1937; Williamson, 1975, 1985) and the theory of industry life cycles (Keppler, 1996; Keppler \& Grady, 1990; Keppler \& Simons, 2000) can offer only partial explanations due to their focus external to the firm.

Country effects were the second most important class of effects and were rarely explored by previous studies since most of them used samples of only one country, concentrating on the economic environment of the U.S. and United Kingdom, with rare exceptions. Among these were Keating (1974), who covered Australian firms, and Sutton (1995), who had indications of country effects. This research demonstrates that country matters when it comes to firm growth.

The fact the industry had such a low relevance in variance explanation is clearly at odds with the relevance given to industry in economics. The existence of industry effects is mentioned, but not quantified, in several previous studies (Hall, 1987; Mansfield, 1962; Singh \& Whittington, 1975). A more recent line of research about industry life cycle (Keppler, 1996; Keppler \& Grady, 1990; Keppler \& Simons, 2000; Reichstein, 2003) attempts to associate growth of individual firms to an evolution pattern of the industry as a whole.

Year effects were also superficially covered by previous studies. Hall (1987) mentioned, but did not quantify, that macroeconomic factors affect all companies in certain years and could be a relevant source of variation. This research found a moderate year effect, more relevant in the annual growth rates where it reaches 3 to $4 \%$ of total variance.

\section{Variance Composition in the Different SIC Divisions}

As pointed out by McGahan and Porter (1997), analyzing the variance of financial performance, variance composition can vary significantly when seen by the different SIC divisions or economic sectors. These SIC divisions represent groups of similar industries and are the basis of the SIC classification.
A: Agriculture, forestry and fishing - SIC 0100 to 0999
B: Mining - SIC 1000 to 1499
C: Construction - SIC 1500 to 1999
D: Manufacturing - SIC 2000 to 3999
E: Transport, communications, electric, gas, and sanitary service - SIC 4000 to 4999
F: Wholesale trade - SIC 5000 to 5199
G: Retail trade - SIC 5200 to 5999
I: Services - SIC 7000 to 8999

Divisions $\mathrm{F}$ and $\mathrm{G}$ were joined in the analysis, and divisions $\mathrm{H}$ (Finance, insurance, and real estate), and $\mathbf{J}$ (Public administration) were not included. Table 2 and Table 3 present the results for growth in revenues and total assets respectively using the simple model with no interactions accounted for. Tables 4 and 5 present the results of the full model with all interactions. The model with interactions 
could not be calculated for the total sample due to computational limitations, so it is presented only by division.

Table 2: Variance Composition of Three-year Compound Revenue Growth per SIC Division, Basic Model with no Interactions

\begin{tabular}{lrrrrrrr}
\hline & A & \multicolumn{1}{c}{ B } & C & D & E & F \& G & I \\
Year & $5.9 \%$ & $2.2 \%$ & $0.6 \%$ & $1.6 \%$ & $0.2 \%$ & $1.1 \%$ & $4.5 \%$ \\
Firm & $25.1 \%$ & $39.1 \%$ & $35.5 \%$ & $43.1 \%$ & $46.6 \%$ & $50.4 \%$ & $45.3 \%$ \\
Country & $27.0 \%$ & $2.6 \%$ & $28.6 \%$ & $10.9 \%$ & $4.9 \%$ & $9.8 \%$ & $10.1 \%$ \\
Industry & $6.4 \%$ & $5.3 \%$ & $0.6 \%$ & $1.7 \%$ & $9.8 \%$ & $5.8 \%$ & $2.0 \%$ \\
Model & $64.3 \%$ & $49.2 \%$ & $65.3 \%$ & $57.3 \%$ & $61.5 \%$ & $67.2 \%$ & $61.9 \%$ \\
Unexplained variance & $35.7 \%$ & $50.8 \%$ & $34.7 \%$ & $42.1 \%$ & $38.5 \%$ & $32.8 \%$ & $38.1 \%$ \\
Total & $100.0 \%$ & $100.0 \%$ & $100.0 \%$ & $100.0 \%$ & $100.0 \%$ & $100.0 \%$ & $100.0 \%$ \\
Mean & 6.36 & 16.13 & 4.00 & 5.78 & 9.72 & 6.09 & 16.75 \\
Standard deviation & 17.58 & 24.76 & 15.66 & 16.61 & 19.28 & 16.72 & 24.74 \\
Observations & 439 & 1190 & 1177 & 24232 & 3695 & 6325 & 5812 \\
\hline Son
\end{tabular}

Source: authors' analysis.

Table 3: Variance Composition of Three-year Compound Total Assets Growth per SIC Division, Basic Model with no Interactions

\begin{tabular}{lrrrrrrr}
\hline & $\mathbf{A}$ & $\mathbf{B}$ & $\mathbf{C}$ & $\mathbf{D}$ & $\mathbf{E}$ & $\mathbf{F ~ \& ~ G}$ & $\mathbf{I}$ \\
Year & $8.5 \%$ & $5.5 \%$ & $0.0 \%$ & $1.2 \%$ & $0.5 \%$ & $0.8 \%$ & $4.4 \%$ \\
Firm & $30.0 \%$ & $36.3 \%$ & $42.3 \%$ & $39.8 \%$ & $46.2 \%$ & $46.7 \%$ & $39.3 \%$ \\
Country & $16.1 \%$ & $0.0 \%$ & $22.5 \%$ & $13.0 \%$ & $4.7 \%$ & $15.1 \%$ & $8.5 \%$ \\
Industry & $4.2 \%$ & $13.2 \%$ & $1.5 \%$ & $1.9 \%$ & $4.6 \%$ & $3.4 \%$ & $2.6 \%$ \\
Model & $58.7 \%$ & $54.8 \%$ & $66.3 \%$ & $55.9 \%$ & $56.1 \%$ & $66.0 \%$ & $54.8 \%$ \\
Unexplained variance & $41.3 \%$ & $45.2 \%$ & $33.7 \%$ & $44.1 \%$ & $43.9 \%$ & $34.0 \%$ & $45.2 \%$ \\
Total & $100.0 \%$ & $100.0 \%$ & $100.0 \%$ & $100.0 \%$ & $100.0 \%$ & $100.0 \%$ & $100.0 \%$ \\
Mean & 7.50 & 13.47 & 4.06 & 6.60 & 8.86 & 6.11 & 16.27 \\
Standard deviation & 16.82 & 24.16 & 15.46 & 17.38 & 18.89 & 16.65 & 26.51 \\
Observations & 445 & 1058 & 1158 & 23873 & 3171 & 6319 & 5591 \\
\hline
\end{tabular}

Source: authors' analysis.

Table 4: Variance Composition of Three-year Compound Revenue Growth per SIC Division, Model with Interactions

\begin{tabular}{lrrrrrrr}
\hline & \multicolumn{1}{c}{$\mathbf{A}$} & \multicolumn{1}{c}{ B } & \multicolumn{1}{c}{ C } & \multicolumn{1}{c}{ D } & \multicolumn{1}{c}{ E } & \multicolumn{1}{c}{ F \& G } & \multicolumn{1}{c}{ I } \\
Year & $2.3 \%$ & $1.4 \%$ & $1.3 \%$ & $0.5 \%$ & $0.0 \%$ & $1.5 \%$ & $1.8 \%$ \\
Firm & $23.8 \%$ & $41.8 \%$ & $26.7 \%$ & $44.2 \%$ & $50,0 \%$ & $41.1 \%$ & $47.4 \%$ \\
Country & $6.6 \%$ & $1.8 \%$ & $4.4 \%$ & $9.0 \%$ & $3.1 \%$ & $4.9 \%$ & $7.5 \%$ \\
Industry & $5.2 \%$ & $3.3 \%$ & $2.0 \%$ & $1.6 \%$ & $5.7 \%$ & $4.2 \%$ & $3.8 \%$ \\
Year*Country & $8.9 \%$ & $0.0 \%$ & $17.0 \%$ & $4.4 \%$ & $1.9 \%$ & $6.3 \%$ & $4.3 \%$ \\
Year*Industry & $2.3 \%$ & $2.1 \%$ & $0.0 \%$ & $0.6 \%$ & $2.5 \%$ & $1.3 \%$ & $4.5 \%$ \\
Country*Industry & $23.0 \%$ & $0.0 \%$ & $26.0 \%$ & $1.9 \%$ & $0.4 \%$ & $14.5 \%$ & $0.0 \%$ \\
Model & $72.0 \%$ & $50.3 \%$ & $77.5 \%$ & $62.3 \%$ & $62.7 \%$ & $73.7 \%$ & $69.4 \%$ \\
Unexplained & $28.0 \%$ & $49.7 \%$ & $22.5 \%$ & $37.7 \%$ & $36.8 \%$ & $26.3 \%$ & $30.6 \%$ \\
Variance & $100.0 \%$ & $100.0 \%$ & $100.0 \%$ & $100.0 \%$ & $100.0 \%$ & $100.0 \%$ & $100.0 \%$ \\
Total & & & & & & &
\end{tabular}

Source: authors' analysis. 
Table 5: Variance Composition of Three-year Compound Total Assets Growth per SIC Division, Model with Interactions

\begin{tabular}{lrrrrrrr}
\hline & A & \multicolumn{1}{c}{ B } & \multicolumn{1}{c}{ C } & \multicolumn{1}{c}{ D } & \multicolumn{1}{c}{ E } & F \& G & \multicolumn{1}{c}{ I } \\
Year & $3.6 \%$ & $1.5 \%$ & $0.6 \%$ & $0.9 \%$ & $0.2 \%$ & $1.2 \%$ & $3.0 \%$ \\
Firm & $31.6 \%$ & $38.5 \%$ & $30.4 \%$ & $40.5 \%$ & $45.7 \%$ & $38.1 \%$ & $42.2 \%$ \\
Country & $8.1 \%$ & $0.0 \%$ & $0.0 \%$ & $9.3 \%$ & $2.8 \%$ & $8.9 \%$ & $6.1 \%$ \\
Industry & $3.4 \%$ & $12.0 \%$ & $0.9 \%$ & $1.4 \%$ & $1.9 \%$ & $1.9 \%$ & $1.8 \%$ \\
Year*Country & $8.5 \%$ & $0.0 \%$ & $25.1 \%$ & $6.6 \%$ & $2.8 \%$ & $7.1 \%$ & $4.0 \%$ \\
Year*Industry & $6.7 \%$ & $5.1 \%$ & $0.0 \%$ & $0.7 \%$ & $5.4 \%$ & $1.6 \%$ & $5.5 \%$ \\
Country*Industry & $5.1 \%$ & $0.0 \%$ & $23.7 \%$ & $0.7 \%$ & $2.0 \%$ & $13.7 \%$ & $0.0 \%$ \\
Model & $67.1 \%$ & $57.0 \%$ & $80.8 \%$ & $60.1 \%$ & $60.8 \%$ & $72.4 \%$ & $62.6 \%$ \\
Unexplained & $32.9 \%$ & $43.0 \%$ & $19.2 \%$ & $39.9 \%$ & $39.2 \%$ & $27.6 \%$ & $37.4 \%$ \\
Variance & $100.0 \%$ & $100.0 \%$ & $100.0 \%$ & $100.0 \%$ & $100.0 \%$ & $100.0 \%$ & $100.0 \%$ \\
Total & & & & & & & \\
\hline
\end{tabular}

Source: authors' analysis.

Divisions $\mathrm{C}$ (Construction) and F/G (Wholesale and retail trade) presented the greatest percentages of explained variance by the model reaching figures of 70 to $80 \%$ in the cases where the interactions where included, suggesting more regularity in the dispersion of growth rates. On the other hand, Division B (Mining) presented the lowest percentage of explained variance signaling possibly greater randomness in the distribution of growth rates of firms belonging to this division.

The common pattern is the dominance of firm effects with country effects as a second most important effect and industry and year with small percentages of total variance as found in the total sample. This general pattern is clearly seen in divisions D (Manufacturing), F/G (Wholesale and retail trade), and I (Services), the latter presenting a greater year effect than the other two.

Country is clearly more relevant in some divisions. It matters more in divisions A (Agriculture, forestry, and fishing) and C (construction) and less in B (Mining) and E (Transport, communications, electric, gas, and sanitary service). In division A (Agriculture, forestry and fishing) it even supersedes firm effects for revenue growth. In the full model with interactions (Tables 4 and 5), the combined country effect (combining the direct country effect with the interactions where it takes part) is greater than firm effect for revenue growth. The most important interaction in this case is the one represented by country and industry. This interaction points out that some specific industries in certain countries present a common effect in growth, relating to some country specialization in certain industries.

Industry is slightly more important in divisions B (Mining) and E (Transport, communications, electric, gas, and sanitary service), but never reaches values that come close to firm effects.

\section{Growth Rates x Profitability - a Comparison of Variance Composition}

The main contribution of this paper is to explore the variance composition of firm growth rates, an understudied aspect of firm performance. However, the variance composition of other dimensions of financial performance is also interesting and can be used to relate to previous studies and be used in a comparative basis. This section reports these results for the same sample using two operationalizations of profitability: the traditional return on assets [ROA] used in most studies and the Earnings Before Interest and Tax Margin [EBITM]. The latter was calculated in relation to total sales.

Table 6 presents the overall variance composition, confirming the relevance of firm effects demonstrated in previous studies. When these results are compared with Table 1 , the variance composition of profitability is similar to the variance composition of growth rate when the 3-year compound growth rate is analyzed. The relevant percentage of variance associated with firm effects 
supports in both cases the theoretical foundation of the RBV as the main explanation of this heterogeneity. Country seems also to be more relevant to growth that it is to profitability.

Table 6: Variance Composition of Return on Assets per SIC Division

\begin{tabular}{lrr}
\hline & ROA & EBITM \\
Year & $1.3 \%$ & $1.8 \%$ \\
Firm & $44.3 \%$ & $46.8 \%$ \\
Country & $5.4 \%$ & $3.1 \%$ \\
Industry & $6.7 \%$ & $2.3 \%$ \\
Model & $57.7 \%$ & $54.0 \%$ \\
Unexplained variance & $42.3 \%$ & $46.0 \%$ \\
Total & $100.0 \%$ & $100.0 \%$ \\
\hline Source: authors' analysis. & &
\end{tabular}

When this variance composition is examined by SIC division, a variable pattern can be seen as McGahan and Porter (1997) also found for U.S. firms. The dominance of firm effects confirms the findings of previous studies and is comparable to the composition of growth rates variance shown in Tables 4 and 5. Industry effects are less pronounced in profitability than in growth except for Division E. Country effects are also less relevant although in some particular divisions the country interactions with industry and year reach high percentages (divisions A and C) surpassing firm effects. Tables 4 and 5 also show a similar pattern for these same divisions.

Table 7: Variance Composition of Return on Assets per SIC Division

\begin{tabular}{lrrrrrrr}
\hline & \multicolumn{1}{c}{$\mathbf{A}$} & \multicolumn{1}{c}{ B } & \multicolumn{1}{c}{ C } & \multicolumn{1}{c}{ D } & \multicolumn{1}{c}{ E } & \multicolumn{1}{c}{ F \& G } & \multicolumn{1}{c}{ I } \\
Year & $0.0 \%$ & $0.1 \%$ & $0.0 \%$ & $1.9 \%$ & $0.5 \%$ & $1.6 \%$ & $2.0 \%$ \\
Firm & $25.5 \%$ & $25.9 \%$ & $26.3 \%$ & $43.4 \%$ & $45.7 \%$ & $40.8 \%$ & $51.6 \%$ \\
Country & $0.0 \%$ & $1.7 \%$ & $0.0 \%$ & $4.5 \%$ & $2.8 \%$ & $2.1 \%$ & $1.0 \%$ \\
Industry & $0.1 \%$ & $0.2 \%$ & $1.5 \%$ & $0.0 \%$ & $12.1 \%$ & $1.0 \%$ & $0.0 \%$ \\
Year * Country & $35.2 \%$ & $0.0 \%$ & $4.1 \%$ & $1.4 \%$ & $0.0 \%$ & $3.1 \%$ & $0.0 \%$ \\
Year * Industry & $0.0 \%$ & $6.1 \%$ & $0.4 \%$ & $0.7 \%$ & $1.3 \%$ & $0.5 \%$ & $0.2 \%$ \\
Country * Industry & $0.0 \%$ & $6.5 \%$ & $38.4 \%$ & $0.0 \%$ & $2.3 \%$ & $11.0 \%$ & $0.0 \%$ \\
Model & $60.9 \%$ & $40.4 \%$ & $70.7 \%$ & $52.0 \%$ & $64.7 \%$ & $60.1 \%$ & $54.9 \%$ \\
Unexplained & $39.1 \%$ & $59.6 \%$ & $29.3 \%$ & $48.0 \%$ & $35.3 \%$ & $39.9 \%$ & $45.1 \%$ \\
variance & $100.0 \%$ & $100 \%$ & $100.0 \%$ & $100.0 \%$ & $100.0 \%$ & $100.0 \%$ & $100.0 \%$ \\
Total & & & & & & &
\end{tabular}

Source: authors' analysis.

Table 8: Variance Composition of Earnings before Tax and Interest Margin EBITM per SIC Division

\begin{tabular}{lrrrrrrr}
\hline & \multicolumn{1}{c}{$\mathbf{A}$} & $\mathbf{B}$ & $\mathbf{C}$ & \multicolumn{1}{c}{$\mathbf{D}$} & \multicolumn{1}{c}{ E } & F \& G & \multicolumn{1}{c}{ I } \\
Year & $1.6 \%$ & $0.0 \%$ & $0.0 \%$ & $1.9 \%$ & $0.9 \%$ & $1.6 \%$ & $1.4 \%$ \\
Firm & $36.8 \%$ & $28.4 \%$ & $18.0 \%$ & $42.9 \%$ & $38.7 \%$ & $38.0 \%$ & $50.6 \%$ \\
Country & $0.0 \%$ & $5.8 \%$ & $16.2 \%$ & $4.4 \%$ & $9.5 \%$ & $1.2 \%$ & $5.9 \%$ \\
Industry & $8.3 \%$ & $0.5 \%$ & $3.2 \%$ & $0.3 \%$ & $12.8 \%$ & $0.6 \%$ & $0.4 \%$ \\
Year * Country & $21.2 \%$ & $0.0 \%$ & $20.3 \%$ & $3.8 \%$ & $3.8 \%$ & $5.7 \%$ & $0.0 \%$ \\
Year * Industry & $0.0 \%$ & $4.3 \%$ & $0.0 \%$ & $0.0 \%$ & $0.0 \%$ & $0.6 \%$ & $0.0 \%$ \\
Country * Industry & $0.0 \%$ & $2.3 \%$ & $19.2 \%$ & $1.2 \%$ & $7.2 \%$ & $10.7 \%$ & $0.6 \%$ \\
Model & $67.9 \%$ & $41.3 \%$ & $76.9 \%$ & $54.5 \%$ & $72.8 \%$ & $58.4 \%$ & $58.8 \%$ \\
Unexplained & $32.1 \%$ & $58.7 \%$ & $23.1 \%$ & $45.5 \%$ & $27.2 \%$ & $41.6 \%$ & $41.2 \%$ \\
variance & $100.0 \%$ & $100.0 \%$ & $100.0 \%$ & $100.0 \%$ & $100.0 \%$ & $100.0 \%$ & $100.0 \%$ \\
Total & & & & & & &
\end{tabular}

Source: authors' analysis. 


\section{CONCLUSION}

The main objective of this study is to understand the sources of variability in firm growth rates in an international environment. Using the technique of variance components, we determined that firm specific and idiosyncratic factors account for the largest part of the observed variance. Firm effects explain more than $40 \%$ of the total variance in firm three-year compound growth rates. Coming a distant second, country effects explain some $10 \%$ of total variance, and industry between $5 \%$ and $7 \%$. This variance structure is similar to that of profitability of firms reviewed earlier. It is also similar to the variance composition of return of assets and EBITM of the same sample. Firm effects were again dominant and the main difference is that country seems to matter slightly more for growth than for financial performance.

The dominance of firm effects has important theoretical implications for the study of growth, strongly supporting the original approach of Penrose (1959) based on firm resources and lessening the importance of industry and environment based approaches. Furthermore, since growth is fundamentally firm specific, it suggests that growth could be seen as an alternative or complementary outcome of the use of superior resources, further evidence of business success. As mentioned before, growth and the consequent gain in market share were the basic ideas behind the original idea of competitive advantage. In this perspective, growth could constitute a dynamic dimension of competitive advantage complementing the pure rents of financial approach currently dominant in the RBV development. Recent work on dynamic capabilities seems to acknowledge this (Helfat et al., 2007). Resources can be used to either create and sustain above norm returns or above the norm growth. The expanded competitive advantage concept would then include these two dimensions. The rents dimension would be a more static one while growth clearly dynamic, addressing some of the criticism of RBV as being too static (Priem \& Butler, 2001). Rents would also be more linked to value appropriation and growth to value creation (Rugman \& Verbeke, 2002).

This growth variance structure also has implications for managerial practice and public policies. The dominance of firm effects suggests that managers should concentrate on the development of their companies' resources and their adaptability to market environment and the resource-based view of strategy offers the theoretical foundation for this. On the other hand, the greater relevance of country effects, especially in industries belonging to divisions A (Agriculture, forestry and fishing) and C (Construction) reveals a greater importance of the institutional fabric of the country. Public policies should probably not be targeted at individual industries, since this could not be the most effective way to influence growth. Policies that would lend support to individual companies or that would influence the institutional structure of the country as a whole could be more effective. This implication links the subject firm growth to the work of Porter (1990) on competitiveness of nations and the issue of localization and clusters (Porter, 1994, 2000), as well as to the areas of new institutional economics (North, 1991, 1992) and economy of development (Meier \& Stiglitz, 2001).

This research has several limitations. The first, and maybe the most relevant, has to do with the attempt to operationalize the concept of growth. None of the possible operationalizations is able to capture the complexity of the phenomenon as recognized by Penrose (1959). The convergent validity obtained with two forms of operationalization minimizes this limitation, but does not eliminate it.

Another limitation has to do with the database used. The nonprobabilistic nature of the sample impairs external validity. The sample is, however, sufficiently large for the results to be of interest even if limited to this sample. Moreover, the companies included in the database are the most relevant ones and probably role models for others in each country.

The process to define the final sample also raises some limitations for generalizability. The elimination of outliers did not include cases of extreme growth rates, thereby limiting results to the range of $-50 \%$ to $100 \%$ annual growth rates. Furthermore, the 10-million-dollar limit to revenue 
enabled a direct comparison to previous studies (McGahan \& Porter, 1997), but excluded small companies.

The process of accounting for inflation to compare growth rates in different countries also introduces additional errors due to the choice of a specific index. We may be introducing here a bias that may reflect on the country effect of one of its interactions. A possibility to be explored in future studies is to do more in-depth analysis in specific countries where comparability is better.

The definition of industry is another limitation that is probably reducing the importance of this effect. The use of the 3-digit SIC instead of the full 4-digit one, and the presence of multibusiness firms associated to a single industry are reducing industry definition in the analysis. Also, considering that companies active in different countries, but belonging to the same SIC, are in the same industry may not represent the reality we wish to interpret as industry since, for example, there may be no direct competition between these companies. It may not be possible to define industry in such a global perspective.

The method of variance components is, perhaps, one of the greatest limitations. Despite its extensive use in the strategy literature in analyzing financial performance variance, it presents serious theoretical limitations since it assumes the observations are independent and does not recognize the hierarchical structure of data. The solution would be the development of multilevel models, explored in areas such as education, medicine and psychology and with limited use in business administration (Hofmann, 1997; Misangyi et al., 2006; Raudenbush \& Bryrk, 2002). Future studies can explore relaxing these limitations, extend the study to other measures of performance as Hawawini et al. (2003) did in relation to profitability, and investigate specific groups of companies, especially the Brazilian environment.

\section{ACKNOWLEDGEMENTS}

We thank the two anonymous reviewers and BAR editing staff for their constructive suggestions, which helped to improve the text. We also thank Élvio Corrêa Porto for his thorough research assistance. We gratefully acknowledge the financial support of GVpesquisa and access to the Compustat Global Database provided by the Karl A. Boedecker Library at FGV São Paulo.

\section{REFERENCES}

Acs, Z. J., \& Audretsch, D. B. (1990). The determinants of small firm growth in US manufacturing. Applied Economics, 22(2), 143-153.

Allen, M. G. (1978). Strategic planning with a competitive focus. The McKinsey Quarterly, 14(3), 213.

Ansoff, H. I. (1965). Corporate strategy; an analytic approach to business policy for growth and expansion. New York: McGraw-Hill.

Bandeira-de-Mello, R., \& Marcon, R. (2005). Unpacking firm effects: modeling political alliances in variance decomposition of firm performance in turbulent environments. Brazilian Administration Review, 2(1), 21-37.

Barney, J. B. (1991). Firm resources and sustained competitive advantage. Journal of Management, 17(1), 99-120. 
Baum, J. R., Locke, E. A., \& Smith, K. G. (2001). A multidimensional model of venture growth. Academy of Management Journal, 44(2), 292-303.

Bowman, E. H., \& Helfat, C. (2001). Does corporate strategy matter? Strategic Management Journal, $22(1), 1-26$.

Brito, L. A. L., \& Vasconcelos, F. C. (2004). Performance of Brazilian companies: year effects, line of business and individual firms. Brazilian Administration Review, 1(1), 1-15.

Brush, T. H., \& Bromiley, P. (1997). What does a small corporate effect mean? A variance components simulation of corporate and business effects. Strategic Management Journal, $18(10), 825-835$.

Brush, T. H., Bromiley, P., \& Hendrickx, M. (1999). The relative influence of industry and corporation on business segment performance: an alternative estimate. Strategic Management Journal, 20(6), 519-547.

Carroll, G. R. (1993). A sociological view on how firms differ. Strategic Management Journal, 14(4), 237-249.

Caves, R. E. (1998). Industrial organization and new findings on the turnover and mobility of firms. Journal of Economic Literature, 36(12), 1947-1982.

Chang, S., \& Singh, H. (2000). Corporate and industry effects on business unit competitive position. Strategic Management Journal, 21(7), 739-752.

Claver, E., Molina, J., \& Tari, J. (2002). Firm and industry effects on firm profitability: a spanish empirical analysis. European Management Journal, 20(3), 321-328.

Coase, R. H. (1937). The nature of the firm. Economica, 4(16), 386-405.

Cockburn, I. M., Henderson, R. M., \& Stern, S. (2000). Untangling the origins of competitive advantage. Strategic Management Journal, 21(10/11), 1123-1145.

Cooner, K. R. (1991). A historical comparison of resource-based theory and five schools of thought within industrial organization economics: do we have a new theory of the firm? Journal of Management, 17(1), 121-154.

Dunne, T., Roberts, M. J., \& Samuelson, L. (1989). The growth and failure of U.S. manufacturing plants. The Quarterly Journal of Economics, 104(4), 671-698.

Evans, D. S. (1987a). Tests of alternative theories of firm growth. Journal of Political Economy, 95(4), 657-674.

Evans, D. S. (1987b). The relationship between firm growth, size and age: estimates for 100 manufacturing industries. The Journal of Industrial Economics, 35(4), 567-581.

Foss, N. J. (2002). Edith Penrose: economics and strategic management. In C. Pitelis (Ed.). The growth of the firm (pp. 147-164). Oxford: Oxford University Press.

Geroski, P. A., Machin, S. J., \& Walters, C. F. (1997). Corporate growth and profitability. The Journal of Industrial Economics, 45(2), 171-189.

Gibrat, R. (1931). Les inégalités économiques. Paris: Librairie du Recueil Sirey.

Gluck, F. W., Kaufman, S. P., \& Walleck, A. S. (1980). Strategic management for competitive advantage. Harvard Business Review, 58(4), 154-161. 
Gonçalves, A. R., \& Quintella, R. H. (2006). The role of internal and external factors in the performance of Brazilian companies and its evolution between 1990 and 2003. Brazilian Administration Review, 3(2), 1-14.

Grant, R. M. (1991). The resource-based theory of competitive advantage: implications for strategy formulation. California Management Review, 33(3), 114-135.

Hall, B. H. (1987). The relationship between firm size and firm growth in the U.S. manufacturing sector. The Journal of Industrial Economics, 35(4), 583-606.

Hart, P. E., \& Prais, S. J. (1956). The analysis of business concentration: a statistical approach. Journal of the Royal Statistical Society, 119(2), 150-191.

Hawawini, G., Subramanian, V., \& Verdin, P. (2003). Is performance driven by industry- or firmspecific factors? A new look at the evidence. Strategic Management Journal, 24(1), 1-16.

Helfat, C. E., Finkelstein, S., Mitchell, W., Peteraf, M., Singh, H., Teece, D., \& Winter, S. G. (2007). Dynamic capabilities: understanding strategic change in organizations. Malden, MA: Blackwell Pub.

Hofmann, D. A. (1997). An overview of the logic and rationale of hierarquical linear models. Journal of Management, 23(6), 723-744.

Hymer, S., \& Pashigian, P. (1962). Firm size and rate of growth. The Journal of Political Economy, $70(6), 556-569$.

Ijiri, Y., \& Simon, H. A. (1974). Interpretations of departures from the pareto curve firm-size distribution. The Journal of Political Economy, 82(2), 315-331.

Keating, G. R. (1974). Gibrat's law and the growth of firms. Australian Economic Papers, 13(23), 281-286.

Keppler, S. (1996). Entry, exit, growth, and innovation over the product life cycle. The American Economic Review, 86(3), 562-583.

Keppler, S., \& Grady, E. (1990). The evolution of new industries and the determinants of market structure. The RAND Journal of Economics, 21(1), 27-44.

Keppler, S., \& Simons, K. L. (2000). The making of an oligopoly: firm survival and technological change in the evolution of the U.S. tire industry. The Journal of Political Economy, 108(4), 728760 .

Khanna, T., \& Rivkin, J. (2001). Estimating the performance effect of business groups in emerging markets. Strategic Management Journal, 22(1), 45-74.

Kumar, M. S. (1985). Growth, acquisition activity and firm size: evidence from the United Kingdom. The Journal of Industrial Economics, 33(3), 327-338.

Lippman, S. A., \& Rumelt, R. P. (2003). The payments perspective: microfoundations of resource analysis. Strategic Management Journal, 24(10), 903-927.

Mahoney, J. T., \& Pandian, J. R. (1992). The resource-based view within the conversation of strategic management. Strategic Management Journal, 13(5), 363-380.

Makino, S., Isobe, T., \& Chan, C. M. (2004). Does country matter? Strategic Management Journal, 25(10), 1027-1043.

Mansfield, E. (1962). Entry, Gibrat's law, innovation, and the growth of firms. The American Economic Review, 52(5), 1023-1051. 
McGahan, A. (1999). The performance of US corporations: 1981-1994. Journal of Industrial Economics, 47(4), 373-398.

McGahan, A., \& Porter, M. E. (1997). How much does industry matter, really? Strategic Management Journal, 18(SI), 15-30.

McGahan, A., \& Porter, M. E. (2003). The emergence and sustainability of abnormal profits. Strategic Organization, 1(1), 79-108.

McNamara, G., Vaaler, P. M., \& Devers, C. (2003). Same as it ever was: the search for evidence on increasing hypercompetition. Strategic Management Journal, 24(3), 261-278.

Meier, G., \& Stiglitz, J. (2001). Frontiers of development economis - the future in perspective. Oxford: Oxford University Press.

Misangyi, V. F., Elms, H., Greckhamer, T., \& Lepine, J. (2006). A new perspective on a fundamental debate: a multilevel approach to industry, corporate, and business unit effects. Strategic Management Journal, 27(6), 571-590.

Moraes, E. A. (2005). Análise da decomposição do desempenho de empresas brasileiras utilizando modelos lineares mistos e de componentes de variância. Tese de doutorado. Fundação Getúlio Vargas, São Paulo, SP, Brasil.

Morrisson, J. R., \& Lee, J. G. (1979). The anatomy of strategic thinking. The McKinsey Quarterly, 15(3), 2-9.

Nelson, R. R. (1991). Why do firms differ, and how does it matter? Strategic Management Journal, 12(Special Issue), 61-74.

North, D. C. (1991). Institutions. Journal of Economic Perspectives, 5(1), 97-112.

North, D. C. (1992). Institutions and economic theory. American Economist, 36(1), 3-6.

Ohmae, K. (1978). Effective strategies for competitive success. The McKinsey Quarterly, 14(4), 5059.

Penrose, E. T. (1959). The theory of the growth of the firm. Oxford: Basil Blackwell.

Peteraf, M. A. (1993). The cornerstones of competitive advantage: a resource-based view. Strategic Management Journal, 14(3), 179-191.

Porter, M. E. (1985). Competitive advantage: creating and sustaining superior performance. New York: Free Press; Collier Macmillan.

Porter, M. E. (1990). The competitive advantage of nations. New York: The Free Press.

Porter, M. E. (1994). The role of location on competition. Journal of the Economics of Business, 1(1), 35-39.

Porter, M. E. (2000). Location, competition, and economic development: local cluster in a global economy. Economic Development Quarterly, 14(1), 15-34.

Powell, T. C. (1996). How much does industry matter? An alternative empirical test. Strategic Management Journal, 17(4), 323-334.

Priem, R. L., \& Butler, J. E. (2001). Is the resource-based "view" a useful perspective for strategic management research? Academy of Management Review, 26(1), 22-40. 
Raudenbush, S. W., \& Bryrk, A. S. (2002). Hierarquical linear models: applications and data analysis methods (2nd ed.). Thousand Oaks, CA: Sage.

Reichstein, T. (2003). Firm growth rate distributions, firm size distributions and the industry life cycle. Doctoral dissertation, Aalborg University, Denmark, S. Carolina, United States.

Roquebert, J. A., Phillips, R. L., \& Westfall, P. A. (1996). Markets vs. management: what drives profitability? Strategic Management Journal, 17(10), 653-664.

Rugman, A. M., \& Verbeke, A. (2002). Edith Penrose's contribution to the resource-based view of strategic management. Strategic Management Journal, 23(8). 769-780.

Rumelt, R. P. (1991). How much does industry matter? Strategic Management Journal, 12(3), 167185.

Scherer, F. M., \& Ross, D. (1990). Industrial market structure and economic performance (3rd ed.). Boston: Houghton Mifflin Company.

Schmalensee, R. (1985). Do markets differ much? The American Economic Review, 75(3), 341-351.

Searle, S. R., Casella, G., \& McCulloch, C. E. (1992). Variance Components. New York: John Wiley \& Sons Inc.

Simon, H. A. (1955). On a class of skew distribution functions. Biometrika, 42(3/4), 425-440.

Simon, H. A., \& Bonini, C. P. (1958). The size distribution of business firms. The American Economic Review, 48(4), 607-617.

Singh, A., \& Whittington, G. (1975). The size and growth of firms. Review of Economic Studies, 42(1), 15-26.

South, S. E. (1981). Competitive advantage: the cornerstone of strategic thinking. The Journal of Business Strategy, 1(4), 15-25.

Sutton, J. (1995). The size distribution of businesses, part I: a benchmark case. [Discussion Paper $\mathrm{N}^{\mathrm{o}}$ EI/9]. London School of Economics and Political Science, London, UK.

Sutton, J. (1997). Gibrat's legacy. Journal of Economic Literature, 35(1), 40-59.

Wernerfelt, B. (1984). A resource-based view of the firm. Strategic Management Journal, 5(2), 171180.

Williams, J. R. (1994). Strategy and the search for rents: the evolution of diversity among firms. In R. P. Rumelt, D. E. Schendel, \& D. J. Teece (Eds.). Fundamental issues in strategy (pp. 229-246). Boston: Harvard Business School Press.

Williamson, O. E. (1975). Markets and hierarchies: analysis of antitrust implications. New York: The Free Press.

Williamson, O. E. (1985). The economic institutions of capitalism. New York: The Free Press. 